\title{
Optimal management of perioperative anemia: current perspectives
}

\author{
This article was published in the following Dove Press journal: \\ International Journal of Clinical Transfusion Medicine \\ 24 August 2015 \\ Number of times this article has been viewed
}

\author{
Jad Bou Monsef' \\ Friedrich Boettner ${ }^{2}$ \\ 'Orthopaedic Surgery Department, \\ University of Illinois at Chicago, \\ Chicago, IL, ${ }^{2}$ Adult Reconstruction \\ and Joint Replacement Service, \\ Hospital for Special Surgery, \\ New York, NY, USA
}

\begin{abstract}
Anemia is prevalent in surgical patients and is associated with increased morbidity and mortality. Allogeneic blood transfusions have long been the first choice in addressing the perioperative anemia in surgical patients. Such transfusions have been shown to adversely influence clinical outcome, prolong hospital stay, and increase complications and costs. Evidence of benefit from red blood cell (RBC) transfusion is hard to find, and most benefit from RBC transfusion is assumed and not scientifically proven. As such, perioperative anemia bears a significant clinical and economic impact on the health care landscape. Blood management relies on sustainable and cost-efficient interventions individualized to each patient and risk level. Restrictive transfusion triggers coupled to a multimodal strategy for reducing blood loss should be adopted as the standard of care in surgical patients. The approach aims at optimizing patient preoperative status and RBC stock as well as minimizing perioperative blood loss.

Keywords: blood management, allogeneic, autologous, transfusion, erythropoietin, tranexamic acid, reinfusion, surgery
\end{abstract}

\section{Introduction}

Anemia is common in patients undergoing surgery and is reported in up to one out of four patients preoperatively. ${ }^{1-6}$ The percentage of anemic patients increases postoperatively, not only secondary to surgical blood loss but also from the ensuing systemic inflammatory response that in turn inhibits erythropoiesis and creates a state of functional iron deficiency despite normal iron stores. ${ }^{7,8}$ Anemia is associated with increased risk of adverse outcomes, longer hospital stay, and higher morbidity and mortality. ${ }^{9-11}$ Even mild anemia was shown to increase relative risk of adverse events by $30 \%-40 \% .{ }^{11}$ It is also the major predictor of the need for transfusion of allogeneic blood. ${ }^{12}$ Other factors such as age, sex, and body mass index contribute to perioperative risk of transfusion. ${ }^{13}$ Risks of allogeneic transfusion are rare but can be life threatening. One of the most devastating risks of allogeneic blood is clerical error, which takes place in 1:20,000-24,000 transfusions. ${ }^{14}$ Inherent risks of allogeneic transfusions persist in the form of an increased susceptibility and transmission of infections, transfusion reactions, altered immune response, circulatory overload, and transfusion-related acute lung injury. ${ }^{15,16}$ Therefore, blood transfusions are independently associated with surgical complications, infections, poorer function and recovery, and overall increased mortality, hospital stay, and costs..$^{10,17-20}$

A growing awareness of the risks of perioperative anemia and blood transfusion has highlighted the need for comprehensive blood management in surgical patients. Blood management is a multimodal approach that relies on three pillars: optimizing
Correspondence: Friedrich Boettner Adult Reconstruction and Joint Replacement Service, Hospital for Special Surgery, 535 East 70th Street, New York, NY 1002I, USA

Tel +l 2I2 7742 2I27

Email boettnerf@hss.edu
International Journal of Clinical Transfusion Medicine 2015:3 65-73 65

Dovepress

http://dx.doi.org/10.2147/IJCTM.S61917 (c) (i) (5) $\odot 215$ Bou Monsef and Boettner. This work is published by Dove Medical Press Limited, and licensed under Creative Commons Attribution - Non Commercial (unported, v3.0) License. The full terms of the License are available at http://creativecommons.org/licenses/by-nc/3.0/. Non-commercial uses of the work are permitted wirut ant permission from Dove Medical Press Limited, provided the work is properly attributed. Permissions beyond the scope of the License are administered by Dove Medical Press Limited. Information on how to request permission may be found at: http://www.dovepress.com/permissions.php 
erythropoiesis, minimizing perioperative blood loss, and optimizing the patient-specific physiological reserve of anemia. ${ }^{21}$ The World Health Organization (WHO) has recognized the importance of perioperative blood management (World Health Alliance resolution A 63.12) and has urged all member countries to adopt it as standard of care. ${ }^{22}$ This primarily advocates going beyond the concept of appropriate use of blood and addressing modifiable risk factors that increase the risk of transfusion before the need arises for one. ${ }^{23}$ The move to adopt patient blood management is driven not only by the lack of efficacy and safety of current transfusion practices but also by their direct and indirect costs and the burden on health care resources. ${ }^{24,25}$ Blood management relies on sustainable and cost-efficient interventions individualized to each patient and risk level. It has been identified as one of the ten overlooked opportunities for significant performance improvement and cost savings for hospitals and health systems. ${ }^{26}$ Blood management options encompass the preoperative workup and optimization, the surgery itself, and the postoperative period.

\section{Preoperatively}

Anemia is defined by the WHO as having hemoglobin $(\mathrm{Hb})<13 \mathrm{~g} / \mathrm{dL}$ in men, $<12 \mathrm{~g} / \mathrm{dL}$ in nonpregnant women, and $<11 \mathrm{~g} / \mathrm{dL}$ in pregnant women, with $\sim 1.26$ billion people affected worldwide. ${ }^{27}$ Identifying patients at risk of requiring transfusions and optimization of their $\mathrm{Hb}$ level is key to reduce blood loss and transfusion requirements, and to decrease morbidity and mortality in the perioperative period. The workup includes the detection, evaluation, and treatment of anemia prior to the surgery, as well as the optimal management of medical conditions or medications that may interfere with coagulation and bleeding. The main causes of anemia in the general population are iron, folate, and vitamin B12 deficiency, hemoglobinopathies, and renal failure. This may be compounded by the condition for which the patient is undergoing surgery. Preoperative blood management options aim at optimization of blood stores and include iron supplementation, use of erythropoiesis-stimulating agents (ESAs), and preoperative autologous blood donation (PABD).

\section{Iron and ESAs}

Preoperative iron has shown benefits in both anemic and nonanemic patients. ${ }^{28,29}$ Since the mobilization of iron from ferritin stores is slow, iron supplementation is advocated even with normal ferritin levels. ${ }^{30}$ Intravenous administration is significantly more effective in inducing the erythropoietic response, ${ }^{31}$ and is of particular use in patients with anemia of chronic disease. ${ }^{30}$ Such patients do not typically respond to oral iron due to impaired intestinal absorption and the increased sequestration of iron in macrophages. ${ }^{32}$ Several studies and meta-analyses have established the efficacy of intravenous iron in increasing $\mathrm{Hb}$ levels and reducing transfusion rates, including in patients on dialysis. ${ }^{33-36}$ Intravenous iron is a safer alternative to blood transfusion, ${ }^{28}$ and its effect is more pronounced when coupled with ESAs. ${ }^{35,37}$ Side effects are usually mild and include anaphylaxis, which is less common with the newer formulations.

The erythropoietic response is physiologically triggered by blood loss in surgery, with erythroid hyperplasia visible after 3-6 days and reaching maximal response in 7-10 days. ${ }^{38}$ ESAs are effective at increasing $\mathrm{Hb}$ levels by the equivalent of 1 unit of blood per week, given adequate iron supplementation. Several studies have supported the effectiveness of ESAs in decreasing the risk of transfusion in the perioperative setting with no reported increase in thromboembolic events. ${ }^{39-42}$ The concern of the risk of thrombosis associated with ESAs was raised in trials where the incidence of venous thromboembolism was higher in the group that received preoperative ESA. ${ }^{43}$ An important distinction is that the thromboembolic risks of ESAs were reported in trials with patients with chronic renal disease who received higher doses over longer time periods, as well as high-risk populations such as critically ill and cancer patients. ${ }^{44,45}$ In contrast, preoperative ESA in elective surgery utilizes lower doses for shorter durations. ${ }^{46}$ It is important to keep in mind that a higher risk of thromboembolic events might ensue from increased blood viscosity and platelet concentration. Erythropoietin (EPO) is contraindicated for patients with comorbidities that may predispose to adverse side effects, such as uncontrolled arterial hypertension, previous acute myocardial infarction or stroke, unstable angina, and severe carotid stenosis. The US Food and Drug Administration requires a warning to be added to the package inserts to urge the use of deep vein thrombosis (DVT) prophylaxis in surgical patients receiving EPO. ${ }^{47}$ Monitoring $\mathrm{Hb}$ and hematocrit levels in all patients treated with EPO is indicated, as well as using low doses and setting lower target $\mathrm{Hb}$ levels. More common side effects include local skin irritation at the injection site, increased blood pressure, and headaches. ${ }^{48}$ Several different dosing regimens of EPO are available, and iron supplementation is necessary in all cases. The most commonly used approaches are $300 \mathrm{IU} / \mathrm{kg}$ daily for 15 days, starting 10 days before surgery, or $600 \mathrm{IU} / \mathrm{kg}$ on preoperative days 21,14 , and 7 and on the day of surgery. The recommended dosage in cases of blood donation is $600 \mathrm{IU} / \mathrm{kg}$ (or a 40,000 IU vial) 
twice a week. Treatment should be discontinued if $\mathrm{Hb}$ levels reach $15 \mathrm{~g} / \mathrm{dL}$. Blood levels of ferritin, folic acid, and vitamin B12 should be checked and corrected before initiating therapy. ${ }^{43,49-54}$

Patients with chronic conditions such as autoimmune or kidney disease need to be evaluated on an individual basis, as many of them would be in a state of functional iron deficiency. Chronic anemia from inflammation, infections, and malignancies is often mild to moderate. It is important to identify this type of anemia in which enteral iron supplementation has no therapeutic benefits due to sequestration in macrophages and enteric cells. ${ }^{32}$ This can be overcome with the use of intravenous iron, ${ }^{30}$ and higher doses of EPO may be required to trigger sustained erythropoiesis. ${ }^{55}$

\section{Preoperative autologous blood donation}

$\mathrm{PABD}$ as a blood-saving modality in elective procedures offers advantages in terms of safety from infection transmission, early stimulation of erythropoiesis preoperatively, and the dilution of blood resulting in lower red blood cell (RBC) loss intraoperatively. ${ }^{56,57}$ Iron supplementation with or without ESA therapy is key for adequate erythropoiesis. PABD has shown to reduce allogeneic transfusion requirements.,58-60 A Cochrane review as well as other large-scale studies showed significant reduction in exposure to allogeneic blood at the expense of a higher overall transfusion rate (allogeneic and/or autologous). ${ }^{1,61}$ The cost efficacy of PABD may be optimized by restricting its use to anemic patients, thus significantly decreasing the number of units wasted. ${ }^{60,62}$ Autologous blood donation may be of limited use when other blood-saving tools are used, such as hemostatic agents or cell salvage. ${ }^{63}$ Autologous blood donation has not been associated with prolonged hospitalization or increased morbidity or mortality. ${ }^{64}$ However, concerns limiting the widespread adoption of this technique include cost and number of wasted blood units, as well as the potential risks of transfusion reactions, bacterial contamination, and clerical errors. It is also time-consuming and requires a setup in place to adequately handle the blood units. The EPO response in some patients might be insufficient, exacerbating their anemia and increasing the risk of allogeneic transfusion. ${ }^{14}$

\section{Intraoperatively}

Intraoperative anemia can be caused by acute blood loss as well as hemodilution as a result of fluid administration and hypotensive anesthesia. Intraoperative blood management measures rely on minimizing blood loss and recovering the lost blood. This is possible through hypotensive anesthesia techniques, hemodilution, reinfusion devices, and pharmacologic antifibrinolytic agents.

\section{Hypotensive neuraxial anesthesia}

Controlled hypotension is the reduction of the mean arterial pressure to $50-75 \mathrm{mmHg}$ and has been shown to decrease postoperative wound drainage and intraoperative blood loss by up to $40 \% .{ }^{65-67} \mathrm{~A}$ meta-analysis has shown its benefit in orthopedic surgery, ${ }^{68}$ and it has been associated with fewer perioperative blood transfusions, ${ }^{69,70}$ a lower rate of DVT, ${ }^{71,72}$ and a low perioperative mortality rate. ${ }^{73}$ Although the technique has been used safely in patients with hypertension, ischemic heart disease, and in the elderly, it tends to be utilized in healthier patients due to fear of compromising organ perfusion. This technique also results in a cleaner surgical field. Of note, the volume expansion that goes along with deliberate hypotension may lead to a higher degree of hemodilution in the immediate postoperative period. ${ }^{74}$ This could cause a false anemia and should be taken into consideration when interpreting $\mathrm{Hb}$ levels postoperatively.

\section{Acute normovolemic hemodilution}

Acute normovolemic hemodilution (ANH) consists of extracting a certain blood volume from the patient and simultaneously exchanging for crystalloid and/or colloid solution to maintain normovolemia. ${ }^{75}$ The concept is to effectively create a well-tolerated intraoperative anemia and dilute the blood lost in surgical procedures with significant anticipated blood loss such as major cardiac, orthopedic, thoracic, or liver surgery. The activity of coagulation factors and platelets is maintained in the stored blood. ${ }^{15}$ The autologous whole blood is transfused at the end of the procedure and provides red cells, fresh clotting factors, and platelets. As long as normovolemia is preserved, stroke volume and cardiac output increase with no change in heart rate as a result of increased venous return, peripheral vasodilation, and rightward shift of the $\mathrm{Hb}$ dissociation curve. ${ }^{76}$

The technique is similar to PABD, except that it does not require the same logistic setup and is possible in nonelective situations. In a systematic review of its use in different types of surgical procedures (cardiac, hepatic, urologic, and orthopedic), ANH showed a 55\% reduction in the risk of receiving allogeneic blood as well as a reduction in number of allogeneic units transfused by 2.8 units per patient. ${ }^{77}$ However, the review found that ANH offers no significant advantage when associated with a transfusion protocol. ${ }^{77}$ As for the safety of this technique, two meta-analyses found no significant increase in morbidity (myocardial infarction, 
myocardial ischemia, alteration of left ventricular function, DVT, stroke, hypotension, or transfusion reaction), postoperative infection, length of stay, or mortality. ${ }^{75,77}$

While ANH relies on restoring the blood volume with crystalloid and colloid, another approach is hypervolemic hemodilution utilizes crystalloid with no phlebotomy. The rationale for this approach is to dilute the blood lost during surgery. The advantage is that it does not involve any withdrawal of blood and is less time-consuming. The patients must be healthy enough with efficient physiological compensation mechanisms to tolerate acute anemia, and it is contraindicated in patients with coronary artery, renal, pulmonary, and hepatic disease. It has been reported to be comparable to normovolemic hemodilution in significantly reducing perioperative allogeneic blood requirements and cost. $^{78}$

\section{Perioperative cell salvage}

Intraoperative cell salvage involves the collection of drainage or suction blood and its reinfusion during or after the procedure. ${ }^{79}$ Cell salvage systems are able to recover up to $60 \%$ of the blood lost using filtered or unfiltered cell savers $^{56,80}$ and therefore require $\sim 750 \mathrm{~mL}$ of blood loss to salvage a unit of packed RBCs. ${ }^{77,80}$ Cell savers are commonly used in cardiac, vascular, orthopedic, liver, and neurosurgical procedures and have been shown to reduce exposure to allogeneic blood by $38 \%$ and an average saving of 0.68 units of RBC per patient. ${ }^{81-83}$ Similar to ANH, this modality has been reported to be of limited use when associated with a restrictive transfusion strategy. ${ }^{84}$ It has not been associated with increased mortality or morbidity, and its contraindications include cancer, intraoperative contamination of the surgical field, and infection. ${ }^{77,85,86}$ Of note, potential complications include the activation of intravascular coagulation with increased capillary permeability causing acute lung injury and renal failure. This is known as salvaged blood syndrome and is related to the dilution of salvaged blood from large quantities of saline solution which creates deposits of cellular aggregates. In addition, cell-salvaged blood contains no platelets or coagulation factors, and therefore, platelets, fresh-frozen plasma, and cryoprecipitate transfusions are required in cases of massive blood loss. ${ }^{87}$

\section{Hemostatic agents}

Pharmacologic manipulation of the coagulation cascade through different mechanisms that inhibit fibrinolysis or promote coagulation is a major strategy for reducing surgical blood loss. ${ }^{88}$ Hemostatic agents including antifibrinolytics, desmopressin, recombinant factor VIIa, and fibrin sealants have been used to minimize bleeding in situations such as dental extraction, tonsillectomy, prostate surgery, heavy menstrual bleeding, and cardiac surgery, and in patients with hemophilia.

The antifibrinolytics tranexamic acid (TXA) and $\varepsilon$-aminocaproic acid are derivatives of the amino acid lysine. They prevent breakdown of blood clots by inhibiting the proteolytic activity of plasmin on fibrinogen as well as the production of plasmin from plasminogen. TXA is six to ten times more potent than $\varepsilon$-aminocaproic acid and has gained widespread use in recent years, namely in cardiovascular, trauma, and orthopedic surgery. ${ }^{15}$ The use of TXA has shown significant reductions in blood loss and allogeneic blood transfusion requirements in an extensive review of $>25,000$ surgical patients. ${ }^{88}$ TXA has been found to reduce bleeding and improve outcomes, including mortality. The use of TXA in major orthopedic procedures was associated with a reduction in blood loss by a mean of $126 \mathrm{~mL}$ intraoperatively and $408 \mathrm{~mL}$ postoperatively in a meta-analysis of 46 randomized controlled studies including 2,925 patients. ${ }^{89}$ Additionally, the risk of transfusion was decreased by half, and the volume of blood transfused was reduced by a mean of $205 \mathrm{~mL}$. No increase in the risk of thromboembolic events was detected. These results mirror previous meta-analyses reporting significant reduction in blood loss with the use of intravenous and topical TXA by $34 \%$ and $29 \%$, respectively. ${ }^{90,91}$ Similar results were observed in terms of transfusion rate and risk of thromboembolic events. ${ }^{92,93}$ The reduction in postoperative transfusion rates remains the most clinically relevant measure of modalities that target surgical blood loss. TXA has been considered particularly useful in knee replacement as the application of a tourniquet leads to increased activation of local fibrinolysis, platelet dysfunction, venous stasis, and blood vessel wall damage. ${ }^{94}$ Administered topically or intravenously, TXA can decrease blood loss, allogeneic transfusion risk, and volume of autologous blood transfused after total knee arthroplasty ${ }^{95-97}$ Both intravenous (single or repeated bolus dosing or continuous infusion) and topical (intra-articular) administration of TXA have been shown efficient in orthopedic surgery. Topical irrigation doses range from $500 \mathrm{mg}$ to $3 \mathrm{~g}$ in up to $100 \mathrm{~mL}$ of saline and are left in contact for at least 5 minutes prior to wound closure. Intravenous doses used in clinical trials vary significantly, but the most commonly used dose is $10-15 \mathrm{mg} /$ $\mathrm{kg}$. This can be followed by an infusion of $1 \mathrm{mg} / \mathrm{kg} / \mathrm{h}$ until after the surgery as it has a short half-life and is almost completely excreted within 24 hours. $^{15}$

Fibrin sealants encompass a variety of topical agents to promote platelet aggregation or the coagulation cascade. 
Collagen- or plant-based products such as gelatin sponges or compounds containing cellulose act passively by providing a physical structure for contact activation and promotion of platelet aggregation. ${ }^{98}$ Active agents possess intrinsic biological activity and are topically applied biological adhesives that consist of human fibrinogen and thrombin mixed with calcium and serve to initiate the final stages of coagulation. Their hemostatic action is less susceptible to coagulopathies due to clotting factor deficiencies or platelet dysfunction. ${ }^{99}$ They have been determined safe and efficient at reducing $\mathrm{Hb}$ drop, blood drainage volume, hematoma formation, and incidence of blood transfusion. ${ }^{100,101}$ However, fibrin sealants are significantly less cost efficient than TXA or even autologous blood donation. ${ }^{60}$ They also carry a theoretical risk of infection transmission as they are derived from human blood products. Among hemostatic agents, TXA has gained widespread use as cheap and widely available, with lower transfusion rates that reflect on early mobilization, length of stay, and cost.

\section{Postoperatively Surgical drains}

Drains serve to avoid postoperative hematoma formation and the compression of vital structures. By increasing tension and decreasing perfusion, a hematoma could impair wound healing, provide a medium for infection, and cause pain and stiffness resulting in delayed rehabilitation and extended hospital stay. ${ }^{102,103}$ However, drains may also provide a conduit for the entry of bacteria. ${ }^{104,105}$ Ninety percent of the blood is collected within the first 24 hours after which the risk of retrograde infection surpasses any proposed benefit, and the drain should be discontinued. ${ }^{106}$ Closed suction drainage in total joint arthroplasty was found to be associated with a $40 \%$ increase in blood transfusions when compared to controls. ${ }^{107} \mathrm{It}$ is possible to reinfuse less than $1 \mathrm{~L}$ of the blood from a wound drain, filtered or unfiltered, within 6 hours. ${ }^{108}$ A Cochrane meta-analysis failed to detect a significant difference in the incidence of wound infection, hematoma, dehiscence, or reoperations between drained and undrained wounds in orthopedic patients. ${ }^{107}$ More blood transfusions were associated with the use of drains, and more bruising and frequent dressing reinforcement in the control group. The review concluded that there was insufficient evidence to support the routine use of closed suction drainage in orthopedic surgery. ${ }^{14,102,103,107}$

\section{Transfusion threshold}

Blood transfusion has been recognized as one of the most frequently performed and overused procedures by the American
Board of Internal Medicine, with a significant percentage of transfusions found to be inappropriate. ${ }^{109}$ Transfusions do not address the underlying cause of anemia. An analysis of just under one million surgical patients reported that transfusion of a single unit of packed red cells increased the multivariate risk of mortality, wound problems, pulmonary complications, renal dysfunction, systemic sepsis, composite morbidity, and postoperative length of stay, compared to matched patient who did not receive blood. ${ }^{110}$

The American Society of Anesthesiologists (ASA) guidelines recommend $\mathrm{RBC}$ transfusion if the $\mathrm{Hb}$ concentration drops $<6-10 \mathrm{~g} / \mathrm{dL}$. While transfusions in patients with a $\mathrm{Hb}>10 \mathrm{~g} / \mathrm{dL}$ are rarely indicated, there is little debate that patients with a $\mathrm{Hb}<6 \mathrm{~g} / \mathrm{dL}$ should be transfused according to most clinical practice guidelines. ${ }^{111}$ A restrictive strategy for young healthy trauma patients where allogeneic transfusion is not performed in asymptomatic patients at rest unless $\mathrm{Hb}$ drops $<5 \mathrm{~g} / \mathrm{dL}$ was reported to be safe and have a lower complication rate than a more liberal transfusion strategy. ${ }^{112}$ Recent clinical trials have provided Level 1 evidence to support restrictive RBC transfusion practices. ${ }^{113}$ Lower transfusion triggers have been shown to be safe ${ }^{114}$ and effective for patients undergoing cardiac surgery ${ }^{115}$ and critically ill patients. ${ }^{116}$ The FOCUS trial found that elderly (mean age older than 80 years), high-risk (factors for coronary artery disease) patients who have undergone hip fracture surgery tolerate a $\mathrm{Hb}$ trigger as low as $8 \mathrm{~g} / \mathrm{dL}$ (or higher if symptomatic). ${ }^{117} \mathrm{~A}$ Cochrane meta-analysis of prospective randomized trials comparing $\mathrm{Hb}$ thresholds of $>3,700$ patients found that low $\mathrm{Hb}$ thresholds were well tolerated, and reduced blood transfusions by $37 \%$ and perioperative infections by $34 \%$. The meta-analysis concluded that a Hb cut-off level of $7 \mathrm{~g} / \mathrm{dL}$ was appropriate for most patients. ${ }^{118}$ Additionally, a randomized controlled trial of 2,016 elderly patients with history or risk factors of cardiovascular disease who underwent hip surgery demonstrated that mortality rates, inability to walk independently, and in-hospital morbidity rates were similar in liberal versus restrictive transfusion protocols, despite significant fewer transfusions in the restrictive group.

Setting a transfusion trigger is ultimately the function of the underlying health of the patient, the change in the level of $\mathrm{Hb}$, the absolute level of $\mathrm{Hb}$, and any decrease in perfusion. Monitoring for perfusion of vital organs using standard ASA recommendations includes heart rate, blood pressure, oxygen saturation, capnography, and urine output in addition to clinical evaluation. ${ }^{119}$ The American College of Physicians does not identify a discrete $\mathrm{Hb}$ level as a trigger for transfusion. Instead, it recommends basing the decision 
on clinical evaluation, and if needed, transfusing only one unit and reevaluating the situation.

\section{Conclusion}

The changing landscape of health care demands improved quality of care while reducing costs, and highlights the importance of efficient and cost-effective blood management in elective procedures. Future directions in blood management ultimately must rely on defining anemia treatment thresholds in specific patient populations, and a deeper understanding of how patients may be able to tolerate different levels of $\mathrm{Hb}$ reduction based on their individual background, level of conditioning, and associated comorbidities. Evidence of benefit from RBC transfusion is hard to find, and most benefit from $\mathrm{RBC}$ transfusion is assumed and not scientifically proven.

A multimodal strategy for reducing blood loss should be adopted as the standard of care in surgical patients at risk of blood transfusion. The plan of care should be tailored to the individual patient's condition and to the type of procedure to be performed. Individual preoperative assessment of transfusion risk is crucial to identify the best-suited modalities to minimize blood requirements. The use of antifibrinolytic drugs, namely TXA, should be considered in major surgery. The use of intraoperative or postoperative cell salvage (washed or filtered) should be limited to procedures in which cost effectiveness has been established. Bloodless procedures can only be achieved through patient-tailored protocols that employ the best-suited modalities for each individual patient, maximizing efficacy while reducing cost and adverse effects.

\section{Disclosure}

The authors report no conflicts of interest in this work.

\section{References}

1. Rosencher N, Kerkkamp HE, Macheras G, et al; OSTHEO Investigation. Orthopedic surgery transfusion hemoglobin european overview (OSTHEO) study: blood management in elective knee and hip arthroplasty in Europe. Transfusion. 2003;43(4):459-469.

2. Dunkelgrun M, Hoeks SE, Welten GM, et al. Anemia as an independent predictor of perioperative and long-term cardiovascular outcome in patients scheduled for elective vascular surgery. Am J Cardiol. 2008; 101(8):1196-1200.

3. Kendoff D, Tomeczkowski J, Fritze J, Gombotz H, von Heymann C. Präoperative Anämie in der Orthopädie [Preoperative anemia in orthopedic surgery: clinical impact, diagnostics and treatment]. Orthopade. 2011;40(11): 1018-1020, 1023-1015, 1027-1028. German.

4. Dunne JR, Malone D, Tracy JK, Gannon C, Napolitano LM. Perioperative anemia: an independent risk factor for infection, mortality, and resource utilization in surgery. J Surg Res. 2002;102(2):237-244.

5. Bierbaum BE, Callaghan JJ, Galante JO, Rubash HE, Tooms RE, Welch RB. An analysis of blood management in patients having a total hip or knee arthroplasty. J Bone Joint Surg Am. 1999;81(1):2-10.
6. Spahn DR. Anemia and patient blood management in hip and knee surgery: a systematic review of the literature. Anesthesiology. 2010; 113(2):482-495.

7. Clemens J, Spivak JL. Serum immunoreactive erythropoietin during the perioperative period. Surgery. 1994;115(4):510-515.

8. van Iperen CE, Kraaijenhagen RJ, Biesma DH, Beguin Y, Marx JJ, van de Wiel A. Iron metabolism and erythropoiesis after surgery. Br J Surg. 1998;85(1):41-45.

9. Carson JL, Duff A, Poses RM, et al. Effect of anaemia and cardiovascular disease on surgical mortality and morbidity. Lancet. 1996;348(9034):1055-1060.

10. Shander A, Knight K, Thurer R, Adamson J, Spence R. Prevalence and outcomes of anemia in surgery: a systematic review of the literature. Am J Med. 2004;116(Supp1 7A):58S-69S.

11. Musallam KM, Tamim HM, Richards T, et al. Preoperative anaemia and postoperative outcomes in non-cardiac surgery: a retrospective cohort study. Lancet. 2011;378(9800):1396-1407.

12. Stulberg BN, Thomas J. Blood conservation in hip surgery. In: Callaghan JJ, Rosenberg AG, Rubash HE, editors. The Adult Hip. Vol 1. Philadelphia: Lippincott Williams \& Wilkins; 2007:643.

13. Pola E, Papaleo P, Santoliquido A, Gasparini G, Aulisa L, De Santis E. Clinical factors associated with an increased risk of perioperative blood transfusion in nonanemic patients undergoing total hip arthroplasty. J Bone Joint Surg Am. 2004;86-A(1):57-61.

14. Callaghan JJ, Spitzer AI. Blood management and patient specific transfusion options in total joint replacement surgery. Iowa Orthop J. 2000;20:36-45.

15. Tobias JD. Strategies for minimizing blood loss in orthopedic surgery. Semin Hematol. 2004;41(1 Suppl 1):145-156.

16. Goodnough LT. Blood management: transfusion medicine comes of age. Lancet. 2013;381(9880):1791-1792.

17. Eder AF, Dy BA, Barton J, Kennedy JM, Benjamin RJ. The American Red Cross Hemovigilance Program: advancing the safety of blood donation and transfusion. Immunohematology. 2009;25(4):179-185.

18. Blajchman MA. Transfusion immunomodulation or TRIM: what does it mean clinically? Hematology. 2005;10(Suppl 1):208-214.

19. Triulzi DJ, Vanek K, Ryan DH, Blumberg N. A clinical and immunologic study of blood transfusion and postoperative bacterial infection in spinal surgery. Transfusion. 1992;32(6):517-524.

20. Fernandez MC, Gottlieb M, Menitove JE. Blood transfusion and postoperative infection in orthopedic patients. Transfusion. 1992;32(4): 318-322.

21. SABM. Society for the Advancement of Blood Management (SABM) Glossary. Available from: http://www.sabm.org/glossary/patient-bloodmanagement. Accessed March 3, 2015.

22. WHO. Sixty-Third World Health Assembly, WHA 63.12 (Resolution). Availability, Safety and Quality of Blood Products. Available from: http://apps.who.int/gb/ebwha/pdf_files/WHA63/A63_R12-en.pdf. Accessed March 3, 2015.

23. Hofmann A, Farmer S, Shander A. Five drivers shifting the paradigm from product-focused transfusion practice to patient blood management. Oncologist. 2011;16(Suppl 3):3-11.

24. Liumbruno GM, Velati C. The 2013 update of the "Seville Document": a Spanish multidisciplinary alliance for patient blood management. Blood Transfus. 2013;11(4):481-483.

25. Refaai MA, Blumberg N. The transfusion dilemma - weighing the known and newly proposed risks of blood transfusions against the uncertain benefits. Best Pract Res Clin Anaesthesiol. 2013;27(1):17-35.

26. Huron Healthcare. Ten Overlooked Opportunities For Significant Performance Improvement and Cost Savings. Chicago, IL: Huron Consulting Group Inc.; 2012.

27. McLean E, Cogswell M, Egli I, Wojdyla D, de Benoist B. Worldwide prevalence of anaemia, WHO vitamin and mineral nutrition information system, 1993-2005. Public Health Nutr. 2009;12(4):444-454.

28. Beris P, Munoz M, Garcia-Erce JA, Thomas D, Maniatis A, Van der Linden P. Perioperative anaemia management: consensus statement on the role of intravenous iron. Br J Anaesth. 2008;100(5):599-604. 
29. Andrews CM, Lane DW, Bradley JG. Iron pre-load for major joint replacement. Transfus Med. 1997;7(4):281-286.

30. Auerbach M, Coyne D, Ballard H. Intravenous iron: from anathema to standard of care. Am J Hematol. 2008;83(7):580-588.

31. Weiss G, Goodnough LT. Anemia of chronic disease. $N$ Engl $J$ Med. 2005;352(10):1011-1023.

32. Ganz T. Hepcidin, a key regulator of iron metabolism and mediator of anemia of inflammation. Blood. 2003;102(3):783-788.

33. Pieracci FM, Stovall RT, Jaouen B, et al. A multicenter, randomized clinical trial of IV iron supplementation for anemia of traumatic critical illness. Crit Care Med. 2014;42(9):2048-2057.

34. Litton E, Baker S, Erber W, et al. The IRONMAN trial: a protocol for a multicentre randomised placebo-controlled trial of intravenous iron in intensive care unit patients with anaemia. Crit Care Resusc. 2014, 16(4):285-290.

35. Litton E, Xiao J, Ho KM. Safety and efficacy of intravenous iron therapy in reducing requirement for allogeneic blood transfusion: systematic review and meta-analysis of randomised clinical trials. BMJ. 2013;347: f4822.

36. Susantitaphong P, Alqahtani F, Jaber BL. Efficacy and safety of intravenous iron therapy for functional iron deficiency anemia in hemodialysis patients: a meta-analysis. Am J Nephrol. 2014;39(2):130-141.

37. Ralley FE. Erythropoietin and intravenous iron in PBM. Transfus Apher Sci. 2014;50(1):16-19.

38. Kasper DL, Harrison TR. Harrison's Principles of Internal Medicine. 14 ed. New York: McGraw-Hill; 1998.

39. Feagan BG, Wong CJ, Kirkley A, et al. Erythropoietin with iron supplementation to prevent allogeneic blood transfusion in total hip joint arthroplasty. A randomized, controlled trial. Ann Intern Med. 2000;133(11):845-854.

40. Weber EW, Slappendel R, Hémon Y, et al. Effects of epoetin alfa on blood transfusions and postoperative recovery in orthopaedic surgery: the European Epoetin Alfa Surgery Trial (EEST). Eur J Anaesthesiol. 2005;22(4):249-257.

41. Dzieczkowski JS, Anderson KC. Transfusion biology and therapy. In: Longo DL, Kasper DL, Hauser SL, Jameson JL, Loscalzo J, Fauci AS, editors. Harrison's Principles of Internal Medicine. 18th ed. New York: McGraw-Hill; 2011:586-593.

42. Alsaleh K, Alotaibi GS, Almodaimegh HS, Aleem AA, Kouroukis CT. The use of preoperative erythropoiesis-stimulating agents (ESAs) in patients who underwent knee or hip arthroplasty: a meta-analysis of randomized clinical trials. J Arthroplasty. 2013;28(9):1463-1472.

43. Faris PM, Ritter MA, Abels RI. The effects of recombinant human erythropoietin on perioperative transfusion requirements in patients having a major orthopaedic operation. The American Erythropoietin Study Group. J Bone Joint Surg Am. 1996;78(1):62-72.

44. Gao S, Ma JJ, Lu C. Venous thromboembolism risk and erythropoiesisstimulating agents for the treatment of cancer-associated anemia: a meta-analysis. Tumour Biol. 2014;35(1):603-613.

45. Mesgarpour B, Heidinger BH, Schwameis M, et al. Safety of off-label erythropoiesis stimulating agents in critically ill patients: a meta-analysis. Intensive Care Med. 2013;39(11):1896-1908.

46. Tran DH, Wong GT, Chee YE, Irwin MG. Effectiveness and safety of erythropoiesis-stimulating agent use in the perioperative period. Expert Opin Biol Ther. 2014;14(1):51-61.

47. Kumar A. Perioperative management of anemia: limits of blood transfusion and alternatives to it. Cleve Clin J Med. 2009;76(Suppl 4):S112-S118.

48. Glassner PJ, Slover JD, Bosco JA 3rd, Zuckerman JD. Blood, bugs, and motion - what do we really know in regard to total joint arthroplasty? Bull NYU Hosp Jt Dis. 2011;69(1):73-80.

49. Cheung W, Minton N, Gunawardena K. Pharmacokinetics and pharmacodynamics of epoetin alfa once weekly and three times weekly. Eur $J$ Clin Pharmacol. 2001;57(5):411-418.

50. Cheung WK, Natarajan J, Sanders M, Vercammen E. Comparative pharmacokinetics, safety, and tolerability after subcutaneous administration of recombinant human erythropoietin formulated with different stabilizers. Biopharm Drug Dispos. 2000;21(6):211-219.
51. Faris PM, Ritter MA, Keating EM, Valeri CR. Unwashed filtered shed blood collected after knee and hip arthroplasties. A source of autologous red blood cells. J Bone Joint Surg Am. 1991;73(8):1169-1178.

52. Goodnough LT, Rudnick S, Price TH, et al. Increased preoperative collection of autologous blood with recombinant human erythropoietin therapy. N Engl J Med. 1989;321(17):1163-1168.

53. Goodnough LT, Monk TG, Andriole GL. Erythropoietin therapy. N Engl J Med. 1997;336(13):933-938.

54. Rosencher N, Woimant G, OzierY, Conseiller C. Stratégie préopératoire d'épargne sanguine homologue et érythropoiétine en péri-chirurgie [Preoperative strategy for homologous blood salvage and peri-operative erythropoietin]. Transfus Clin Biol. 1999;6(6):370-379. French.

55. van der Putten K, Braam B, Jie KE, Gaillard CA. Mechanisms of disease: erythropoietin resistance in patients with both heart and kidney failure. Nat Clin Pract Nephrology. 2008;4(1):47-57.

56. Sculco TP. Global blood management in orthopaedic surgery. Clin Orthop Relat Res. 1998;357:43-49.

57. Stanisavljevic S, Walker RH, Bartman CR. Autologous blood transfusion in total joint arthroplasty. J Arthroplasty. 1986;1(3):207-209.

58. Bern MM, Bierbaum BE, Katz JN, Losina E. Autologous blood donation and subsequent blood use in patients undergoing total knee arthroplasty. Transfus Med. 2006;16(5):313-319.

59. Billote DB, Glisson SN, Green D, Wixson RL. Efficacy of preoperative autologous blood donation: analysis of blood loss and transfusion practice in total hip replacement. J Clin Anesth. 2000;12(7):537-542.

60. Bou Monsef J, Buckup J, Mayman D, Marx R, Ranawat A, Boettner F. Targeted preoperative autologous blood donation in total knee arthroplasty reduces the need for postoperative transfusion. HSS J. 2013; 9(3):214-217.

61. Henry DA, Carless PA, Moxey AJ, et al. Pre-operative autologous donation for minimising perioperative allogeneic blood transfusion. Cochrane Database Syst Rev. 2002;(2):CD003602.

62. Bou Monsef J, Figgie MP, Mayman D, Boettner F. Targeted preoperative autologous blood donation: a prospective study of two thousand and three hundred and fifty total hip arthroplasties. Int Orthop. 2014;38(8):1591-1595.

63. Bou Monsef J, Buckup J, Waldstein W, Cornell C, Boettner F. Fibrin sealants or cell saver eliminate the need for autologous blood donation in anemic patients undergoing primary total knee arthroplasty. Arch Orthop Trauma Surg. 2014;134(1):53-58.

64. Munoz M, Garcia-Erce JA, Villar I, Thomas D. Blood conservation strategies in major orthopaedic surgery: efficacy, safety and European regulations. Vox Sang. 2009;96(1):1-13.

65. Sharrock NE, Salvati EA. Hypotensive epidural anesthesia for total hip arthroplasty: a review. Acta Orthop Scand. 1996;67(1):91-107.

66. Nelson CL, Bowen WS. Total hip arthroplasty in Jehovah's Witnesses without blood transfusion. J Bone Joint Surg Am. 1986;68(3): 350-353.

67. Richman JM, Rowlingson AJ, Maine DN, Courpas GE, Weller JF, Wu CL. Does neuraxial anesthesia reduce intraoperative blood loss? A meta-analysis. J Clin Anesth. 2006;18(6):427-435.

68. Paul JE, Ling E, Lalonde C, Thabane L. Deliberate hypotension in orthopedic surgery reduces blood loss and transfusion requirements: a meta-analysis of randomized controlled trials. Can J Anaesth. 2007; 54(10):799-810.

69. Sharrock NE, Mineo R, Urquhart B, Salvati EA. The effect of two levels of hypotension on intraoperative blood loss during total hip arthroplasty performed under lumbar epidural anesthesia. Anesth Analg. 1993;76(3):580-584.

70. Tenholder M, Cushner FD. Intraoperative blood management in joint replacement surgery. Orthopedics. 2004;27(6 Suppl):s663-s668.

71. Sharrock NE, Hargett MJ, Urquhart B, et al. Factors affecting deep vein thrombosis rate following total knee arthroplasty under epidural anesthesia. J Arthroplasty. 1993;8(2):133-139.

72. Lieberman JR, Huo MM, Hanway J, Salvati EA, Sculco TP, Sharrock NE. The prevalence of deep venous thrombosis after total hip arthroplasty with hypotensive epidural anesthesia. J Bone Joint Surg Am. 1994;76(3):341-348. 
73. Sharrock NE, Cazan MG, Hargett MJ, Williams-Russo P, Wilson PD Jr. Changes in mortality after total hip and knee arthroplasty over a ten-year period. Anesth Analg. 1995;80(2):242-248.

74. Monsef JB. Hypotensive anesthesia may result in false anemia and increase transfusion requirements in total hip arthroplasty. $J$ Anesth Clin Res. 2014;5:425.

75. Shander A, Rijhwani TS. Acute normovolemic hemodilution. Transfusion. 2004;44(12 Suppl):26S-34S.

76. Kreimeier U, Messmer K. Hemodilution in clinical surgery: state of the art 1996. World J Surg. 1996;20(9):1208-1217.

77. Carless P, Moxey A, O'Connell D, Henry D. Autologous transfusion techniques: a systematic review of their efficacy. Transfus Med. 2004; 14(2):123-144.

78. Kumar R, Chakraborty I, Sehgal R. A prospective randomized study comparing two techniques of perioperative blood conservation: isovolemic hemodilution and hypervolemic hemodilution. Anesth Analg. 2002;95(5):1154-1161. [table of contents].

79. Moonen AF, Neal TD, Pilot P. Peri-operative blood management in elective orthopaedic surgery. A critical review of the literature. Injury. 2006;37(Supp1 5):S11-S16.

80. Flynn JC, Metzger CR, Csencsitz TA. Intraoperative autotransfusion (IAT) in spinal surgery. Spine. 1982;7(5):432-435.

81. Huet C, Salmi LR, Fergusson D, Koopman-van Gemert AW, Rubens F, Laupacis A. A meta-analysis of the effectiveness of cell salvage to minimize perioperative allogeneic blood transfusion in cardiac and orthopedic surgery. International Study of Perioperative Transfusion (ISPOT) Investigators. Anesth Analg. 1999;89(4): 861-869.

82. Carless PA, Henry DA, Moxey AJ, O’Connell D, Brown T, Fergusson DA. Cell salvage for minimising perioperative allogeneic blood transfusion. Cochrane Database Syst Rev. 2010;(4):CD001888.

83. Woolson ST, Wall WW. Autologous blood transfusion after total knee arthroplasty: a randomized, prospective study comparing predonated and postoperative salvage blood. J Arthroplasty. 2003;18(3): 243-249.

84. Thomassen BJ, den Hollander PH, Kaptijn HH, Nelissen RG, Pilot P. Autologous wound drains have no effect on allogeneic blood transfusions in primary total hip and knee replacement: a three-arm randomised trial. Bone Joint J. 2014;96-B(6):765-771.

85. Hansen E, Hansen MP. Reasons against the retransfusion of unwashed wound blood. Transfusion. 2004;44(12 Suppl):45S-53S.

86. Goodnough LT, Brecher ME, Kanter MH, AuBuchon JP. Transfusion medicine. Second of two parts - blood conservation. $N$ Engl J Med. 1999;340(7):525-533.

87. Kuppurao L, Wee M. Perioperative cell salvage. CEACCP. 2010;10(4): 104-108.

88. Henry DA, Carless PA, Moxey AJ, et al. Anti-fibrinolytic use for minimising perioperative allogeneic blood transfusion. Cochrane Database Syst Rev. 2007;(4):CD001886.

89. Huang F, Wu D, Ma G, Yin Z, Wang Q. The use of tranexamic acid to reduce blood loss and transfusion in major orthopedic surgery: a meta-analysis. J Surg Res. 2014;186(1):318-327.

90. Ker K, Prieto-Merino D, Roberts I. Systematic review, meta-analysis and meta-regression of the effect of tranexamic acid on surgical blood loss. Br J Surg. 2013;100(10):1271-1279.

91. Ker K, Beecher D, Roberts I. Topical application of tranexamic acid for the reduction of bleeding. Cochrane Database Syst Rev. 2013;7: CD010562.

92. Alshryda S, Sukeik M, Sarda P, Blenkinsopp J, Haddad FS, Mason JM. A systematic review and meta-analysis of the topical administration of tranexamic acid in total hip and knee replacement. Bone Joint J. 2014;96-B(8):1005-1015.

93. Poeran J, Rasul R, Suzuki S, et al. Tranexamic acid use and postoperative outcomes in patients undergoing total hip or knee arthroplasty in the United States: retrospective analysis of effectiveness and safety. BMJ. 2014;349:g4829.
94. Reikeras O, Clementsen T. Time course of thrombosis and fibrinolysis in total knee arthroplasty with tourniquet application. Local versus systemic activations. J Thromb Thrombolys. 2009;28(4):425-428.

95. Good L, Peterson E, Lisander B. Tranexamic acid decreases external blood loss but not hidden blood loss in total knee replacement. $\mathrm{Br} J$ Anaesth. 2003;90(5):596-599.

96. Wong J, Abrishami A, El Beheiry H, et al. Topical application of tranexamic acid reduces postoperative blood loss in total knee arthroplasty: a randomized, controlled trial. J Bone Joint Surg Am. 2010;92(15):2503-2513.

97. Oremus K, Sostaric S, Trkulja V, Haspl M. Influence of tranexamic acid on postoperative autologous blood retransfusion in primary total hip and knee arthroplasty: a randomized controlled trial. Transfusion. 2014;54(1):31-41.

98. Schonauer C, Tessitore E, Barbagallo G, Albanese V, Moraci A. The use of local agents: bone wax, gelatin, collagen, oxidized cellulose. Eur Spine J. 2004;13(Suppl 1):S89-S96.

99. Tse EY, Cheung WY, Ng KF, Luk KD. Reducing perioperative blood loss and allogeneic blood transfusion in patients undergoing major spine surgery. J Bone Joint Surg Am. 2011;93(13):1268-1277.

100. Li ZJ, Fu X, Tian P, et al. Fibrin sealant before wound closure in total knee arthroplasty reduced blood loss: a meta-analysis. Knee Surg Sport Traumatol Arthros. 2015;23:2019-2025.

101. Liu J, Cao JG, Wang L, Ma XL. Effect of fibrin sealant on blood loss following total knee arthroplasty: a systematic review and metaanalysis. Int J Surg. 2014;12(2):95-102.

102. Alexander JW, Korelitz J, Alexander NS. Prevention of wound infections. A case for closed suction drainage to remove wound fluids deficient in opsonic proteins. Am J Surg. 1976;132(1):59-63.

103. Waugh TR, Stinchfield FE. Suction drainage of orthopaedic wounds. J Bone Joint Surg Am. 1961;43-A:939-946.

104. Casey BH. Bacterial spread in polyethylene tubing. A possible source of surgical wound contamination. Med J Aust. 1971;2(14):718-719.

105. Willett KM, Simmons CD, Bentley G. The effect of suction drains after total hip replacement. J Bone Joint Surg Br. 1988;70(4):607-610.

106. Drinkwater CJ, Neil MJ. Optimal timing of wound drain removal following total joint arthroplasty. J Arthroplasty. 1995;10(2):185-189.

107. Parker MJ, Livingstone V, Clifton R, McKee A. Closed suction surgical wound drainage after orthopaedic surgery. Cochrane Database Syst Rev. 2007;(3):CD001825.

108. Taylor SE, Cross MH. Clinical strategies to avoid blood transfusion. Anaesth Intensive Care Med. 2013;14(2):48-50.

109. Foundation A. Five Things Physicians and Patients Should Question. Philadelphia, PA: Choosing Wisely; 2012.

110. Ferraris VA, Davenport DL, Saha SP, Austin PC, Zwischenberger JB. Surgical outcomes and transfusion of minimal amounts of blood in the operating room. Arch Surg. 2012;147(1):49-55.

111. American Society of Anesthesiologists Task Force on Perioperative Blood Transfusion and Adjuvant Therapies. Practice guidelines for perioperative blood transfusion and adjuvant therapies: an updated report by the American Society of Anesthesiologists Task Force on Perioperative Blood Transfusion and Adjuvant Therapies. Anesthesiology. 2006;105(1):198-208.

112. Mullis B, Fisk E, Weaver D, Zhao Q, Daggy J, Di Cesare PE. Anemia versus transfusion: does blood conservation increase the risk of complications? Am J Orthop (Belle Mead NJ). 2015;44(1): E11-E16.

113. Goodnough LT, Shah N. Is there a 'Magic' hemoglobin number? clinical decision support promoting restrictive blood transfusion practices. Am J Hematol. 2015; doi 10.1002/ajh.24101.

114. Weiskopf RB, Aminoff MJ, Hopf HW, et al. Acute isovolemic anemia does not impair peripheral or central nerve conduction. Anesthesiology. 2003;99(3):546-551.

115. Bracey AW, Radovancevic R, Riggs SA, et al. Lowering the hemoglobin threshold for transfusion in coronary artery bypass procedures: effect on patient outcome. Transfusion. 1999;39(10):1070-1077. 
116. Hébert PC, Wells G, Blajchman MA, et al. A multicenter, randomized, controlled clinical trial of transfusion requirements in critical care. Transfusion Requirements in Critical Care Investigators, Canadian Critical Care Trials Group. N Engl J Med. 1999;340(6):409-417.

117. Carson JL, Terrin ML, Noveck H, et al; FOCUS Investigators. Liberal or restrictive transfusion in high-risk patients after hip surgery. $N E n g l$ J Med. 2011;365(26):2453-2462.
118. Carson JL, Carless PA, Hebert PC. Transfusion thresholds and other strategies for guiding allogeneic red blood cell transfusion. Cochrane Database Syst Rev. 2012;4:CD002042.

119. Manjuladevi M, Vasudeva Upadhyaya K. Perioperative blood management. Indian J Anaesth. 2014;58(5):573-580.

\section{Publish your work in this journal}

International Journal of Clinical Transfusion Medicine is an international, peer-reviewed, open access, online journal publishing clinicalexperimental, policy-making and evidence-based practices of all topics pertaining to clinical transfusion medicine. Original research, short reports, reviews, case reports and commentaries are invited.
The manuscript management system is completely online and includes a very quick and fair peer-review system, which is all easy to use. Visit http://www.dovepress.com/testimonials.php to read real quotes from published authors.

\footnotetext{
Submit your manuscript here: http://www.dovepress.com/international-journal-of-clinical-transfusion-medicine-journal
} 